O.F. Protasenko, PhD, Assoc. Prof.,

A.A. Ivashura, PhD, Assoc. Prof.

Simon Kuznets Kharkiv National University of Economics, 9-A Nauky Ave., Kharkiv, Ukraine, 61166; e-mail: olha.protasenko@hneu.net, andrii.ivashura@hneu.net

\title{
THE ROLE OF ECOLOGICAL SAFETY IN ERGONOMICS DEVELOPMENT
}

О.Ф. Протасенко, А.А. Івашура. Роль екологічної безпеки у розвитку ергономіки. Розглянуто проблему необхідності застосування аспектів екологічної безпеки для підвищення ефективності ергономічних рішень. Актуальність зазначеної проблеми обумовлена наявністю тісного взаємозв'язку між цими поняттями, а також можливістю подальшого їх застосування для розроблення нових заходів і засобів підвищення безпеки людини і навколишнього середовища. Показана недостатність уваги в ергономіці до питань екологізації простору життєдіяльності людини і суспільства. Метою роботи є аналіз і дослідження ролі екологічної безпеки у розвитку сучасної ергономіки. Для дослідження застосовано системний, синергетичний і відтворювальний підходи, застосовані загальнонаукові та спеціальні методи дослідження. Інтеграція екологічних складових в ергономіку дозволяє вважати перспективним застосування її для вирішення завдань із підвищення безпеки людини і суспільства (як нинішнього, так і майбутнього), розширити іiі використання за багатьма напрямками: в теорії і методології, методичному апараті, нормативнотехнічній документації, сучасних розробках, організаційних питаннях та іншими. Окремі положення роботи на рівні постановки питання можуть бути базою для подальших поглиблених досліджень.

Ключові слова: ергономіка, екологічна безпека, навколишнє середовище, безпека життєдіяльності

O.F. Protasenko, A.A. Ivashura. The role of ecological safety in ergonomics development. The problem of a necessity of application of ecological safety aspects for increasing of ergonomics decisions effectiveness is considered. Actuality of the marked problem is conditioned by the presence of close intercommunication between these concepts, and possibility of their further application for development of new events and facilities of human and environment safety increase. The lack of attention in ergonomics to issues of ecologization of human life and society is shown. The aim of the work is analysis and research of ecological safety role in modern ergonomics development. Systematic, sinergistical and reproductive approaches as well as common scientific and special methods of research are applied. Integration of ecological constituents in ergonomics allows to consider perspective application of it for the solution of tasks of improving the safety of human and society (both of present and future); to extend it usage in many directions: in a theory and methodology, methodical vehicle, normatively-technical documentation, modern developments, organizational questions, personal training and other. Separate positions of work at the level of statement of a question can be a base for further deep researches.

Keywords: ergonomics, ecological safety, environment, safety of vital activity

Problem. Under environmental safety, one should understand the state in which the ecological comfort of life is not violated, the ability to withstand the threats to life, the health of all living beings, the person, including his well-being, the right to a safe living environment, sources of life support, natural resources [1]. At present in Ukraine there is no single strategy for ensuring the implementation of the policy of sustainable development of society, taking into account the conditions and requirements of environmental safety in the regions, also almost no accounting of environmental activities, and the existing management structure is ineffective. The leaders of most enterprises ignore the need to introduce environmental management, environmental marketing, environmental audit and other modern security measures into the process of management. The main reason for this situation is the disadvantages of the methodological and normative-legal basis of Ukraine in the field of natural resources and environmental protection.

However, despite the existing problems, the tendencies towards ecologization of the environment of human life are increasingly spread in scientific areas, which are engaged in studying and research-

DOI: .

(C) 2017 The Authors. This is an open access article under the CC BY license (http://creativecommons.org/licenses/by/4.0/). 
ing human rights and its security. Unfortunately, today they have not received proper application in ergonomics, although the social orientation of ecological relations is directly related to its problems, the solution of which is a prerequisite for the further development of this scientific direction. The confirmation of this fact is the definition of the term "ergonomics", which today is as follows: scientific discipline that studies the interaction of man and elements of the technical system, as well as the scope of the application of the principles, theory and methods of this science to ensure human security and improve the efficiency of the system "man-technology-environment" [2]. Thus, based on the above definition, modern ecologization tendencies should become an integral part in solving human security issues. Moreover, ergonomics in today's understanding is the maximum functionality, convenience, safety and ecology that accompany a person in the workplace and in everyday life. It is a criterion for the compatibility of an object, service or process with a person, with the environment. It also defines the degree of suitability (ie safety) for the realization of human needs and the provision of human welfare in general. Hence, ergonomics and environmental safety are interconnected concepts, the combination of which is a necessary step in addressing the issue of increasing the safety of man and the environment.

Based on the above considerations, one can formulate such a scientific problem. It is a necessity to study and analyze the role of ecological safety in the development of modern ergonomics. The urgency of this problem is due to two main factors:

1) the existence of a close relationship between environmental safety and ergonomics;

2) the possibility of further using the results of this integration to develop effective measures and means of ensuring human and environmental safety [3].

Analysis of recent research and publications. Today, the development of ergonomics and the use of its achievements are limited because ergonomics is a complex symbiosis of medical, biological, psychological and technical sciences, which solves specific problems for improving the qualitative and reliable characteristics of systems "man-technology-environment". Only studies and optimizes their separate (so to speak "universal") characteristics, for example, working conditions at the workplace of the operator or psychological indicators of his condition during the activity and other. At the same time, there are almost no works devoted to ecological problems of ergonomics, which deepens the problem of the effective use of its achievements in production and in everyday life. However, there are insufficient studies aimed at studying the impact of environmental factors on the efficiency, efficiency and safety of human-operator activities. Not received their development and work on the systematization of data on the types and effects of environmental impacts on human-operator activities [4, 5].

However, the problem of studying the ecological needs of society is devoted to a considerable number of papers $[6,7,8]$, in which these needs are systematized and even a definite place of ergonomic issues in them. At the same time, the ecological needs of the society are understood by any resources that the state collects from the natural environment in order to ensure the process of sustainable development. Today, the ecological needs of society are reflected in the system of environmental criteria, on the basis of which the relevant state or intergovernmental bodies develop Ecological Standards that are mandatory for implementation. Unfortunately, the level of environmental needs and demand for them is now much lower than necessary to prevent the global environmental imbalance, as current trends in environmentalizing the human and social life space have only begun to develop.

Environmental needs are very diverse and include both material and spiritual components. For example, N. Reimers (“Ecology (Theories, Laws, Rules, Principles and Hypotheses)”, 1994) proposes a classification of needs in which they are derived from the biosocial structure of man, where man and society as a whole are regarded as a system education. The author describes a person as a system consisting of biological, natural-social and social components, and the system of its needs includes anatomical-physiological (biological), ecological, ethical, labor (ergonomic), economic and social needs.

Setting objectives. Thus, the formation of the tendency of ecological orientation of ergonomics for today is a prerequisite for the further development of this science and is one of the main requirements of ergonomics, namely, the safety of human life. Today in the world, taking into account the level of safety, as one of the most important social indicators, is aimed at ensuring the vital needs of 
people and a healthy environment. In Ukraine, this social function of ergonomics is realized mainly with the support of institutional activity of the state and social organizations. In real life, standards for any type of industrial or consumer ergonomics are implemented in occupational safety and health measures, the protection of consumers from the provision of poor quality goods or services, and in the design of modern ergonomic technologies. However, it should not be forgotten that the existing economic mechanisms lobby for their monetary interests in ergonomics, because safety issues are important not only in the end result - the creation of safe and comfortable working conditions for a person, but also the economic costs to achieve it. However, the economic effect should not become a determining factor, since such an approach will lead to the fact that ergonomics from an independent science will gradually become a component of management and lose its main purpose - to provide comfort and safety of the person. That is why, at this stage of its development, ergonomics must acquire a new vision of its main priorities. There are already some changes in this direction, because, unlike the previous stages of development, now the subject of ergonomics is not only the study and evaluation of the influence of the factors of production on the employee, but also others, for example, natural and social environments. Confirmation of this fact is that, when ergonomically evaluating the workplace, attention is drawn not only to the generally accepted indicators and characteristics (for example, the height of the working surface, the anthropometric characteristics of the chair, etc.), but also their ecological component (for example, the environmental characteristics of the materials from which manufactured workplace items). This approach has received some practical implementation [3, 5, 9].

However, in addition to these problems, there are still many important issues in the ergonomics that are not fully disclosed and partly obscure, since their interpretation does not correspond to current trends and needs to be radically revised. An example of this is that when considering the issues of creating a safe working conditions of employee almost does not take into account the system connections of production with the natural system of resource reproduction. That is, they almost do not appreciate which natural resources and in what quantity they need a certain type of production, whether they are renewable or not, the damage that causes their extraction to the environment, and so on. Thus, the important moments that are the basis for creating safe conditions for the life of a modern society not only at the present time, but also for distant periods, are neglected. In addition, the principles of a green economy are not applied in Ukraine today. This does not allow solving the issue of preserving the environment in relation to the ergonomics of the conditions of future society's existence as effectively as possible.

Now it's an undeniable fact that the modern environment loses its natural balance and becomes an economically dependent environment. Such a transformation is the result of a powerful man-made influence of production. It is no longer static, therefore, in the world today, resource and raw material safety is considered the basis of the safety of human life. In ergonomics, the development of this problem is only in the initial stage, which is associated with the preliminary stages of its development. It is known that the main provisions of ergonomics were actively developed until the middle of XX century. The main obstacles to further development were environmental and economic problems and the growth of entropy. This is reflected in the public mind during the economic crisis in the early 70s of the twentieth century. As a result, the theoretical basis for the post-industrial information society was formed with its main problem - a shortage of natural resources. In ergonomics, the negative impact of this problem on human safety began to be addressed only in recent years. For an explanation, let's give an example. In virgin natural ecosystems, entropy is reduced naturally through constant interaction with the environment and the circulation of nutrients, in stable energy outlay. The amount of energy emitting a natural ecosystem in the environment due to self-regulation mechanisms is insignificant. Such natural ecosystems are constantly striving to move into the most organized and stable state. In man-made systems (for example, in industrial enterprises) energy exchange is carried out differently. Flow of substances and energy through the production system do not have a reciprocal positive connection. There is an increase in consumption of natural resources and energy. This leads to the gradual degradation of natural ecosystems, thus, the entropy of technogenic systems grows. The consequences of this process can be accidents and catastrophes, accompanied by significant material, social and oth- 
er losses. So, in order to maintain these systems in working condition (to slow down the growth of entropy as much as possible), it is inevitable to increase energy outlay. This, in turn, poses a threat to the safety of the existence of present and future generations in all spheres of life. All this points to the need to develop an ecological aspect in ergonomics, which will prevent such negative consequences.

Purpose: to analyze and study the role of environmental safety in the development of modern ergonomics.

Results and discussion. In the process of studying this problem in the framework of system and synergistic approaches applied general scientific and special means of research:

1) subject-object, logical, deductive and inductive methods;

2) comparative and structural analysis.

The methodological and theoretical basis of the research are the works of leading specialists of various branches of knowledge. The interdisciplinary nature of the work is due to the need to use the results of such scientific areas as economics, ecology, sociology. The empirical basis of the study was legal acts and the results of their influence both at the national and regional levels. And also official research data of domestic and foreign scientists, reports of international organizations, official statistical reports, materials of periodicals, conferences and seminars on the given problem.

As noted above, to ensure the environmental safety of the environment, it is necessary to consider it through the prism of ergonomics. The easiest way to do this is with a certain example of commodity production. Such an approach would within a social usefulness provide environmental benefits. Any product or service has a set of physical, mechanical, chemical, biological and other properties and performs a certain function through which the consumer receives personal benefit, realizes his wishes and evaluates the welfare and quality of life. Therefore, the traditional general usefulness of a product (service) can be characterized as a functional, which will reflect the subjective benefit of the user. As part of the industrial relations system formed specific interactions, so-called industrial nature management. It includes the obligation and the resulting investments and costs for environmental protection activities, environmental expertise, certification of production, environmental certification and product labeling, identification of pollutants and environmental perturbations in the area of responsibility of the enterprise, environmental insurance, audit, monitoring and so on. Therefore, it can be argued that an inalienable element of the functional usefulness of a product (or service), of course, is its environmental usefulness, which the consumer does not always perceive. Researchers do not always pay attention to the fact that the consumer does not perceive the environmental benefits, but it is important to analyze it to improve the safety of man and society as a whole (from the standpoint of environmental safety and ergonomics). From our point of view, this situation is due to the inadequate level of environmental friendliness of the enterprises (lack of appropriate material and technical base, waste management strategy), low ecological consciousness of consumers, insufficient level of financial well-being of people and other factors. However, this is the most significant impact on the prospect of improving the safety of human life (Fig. 1).

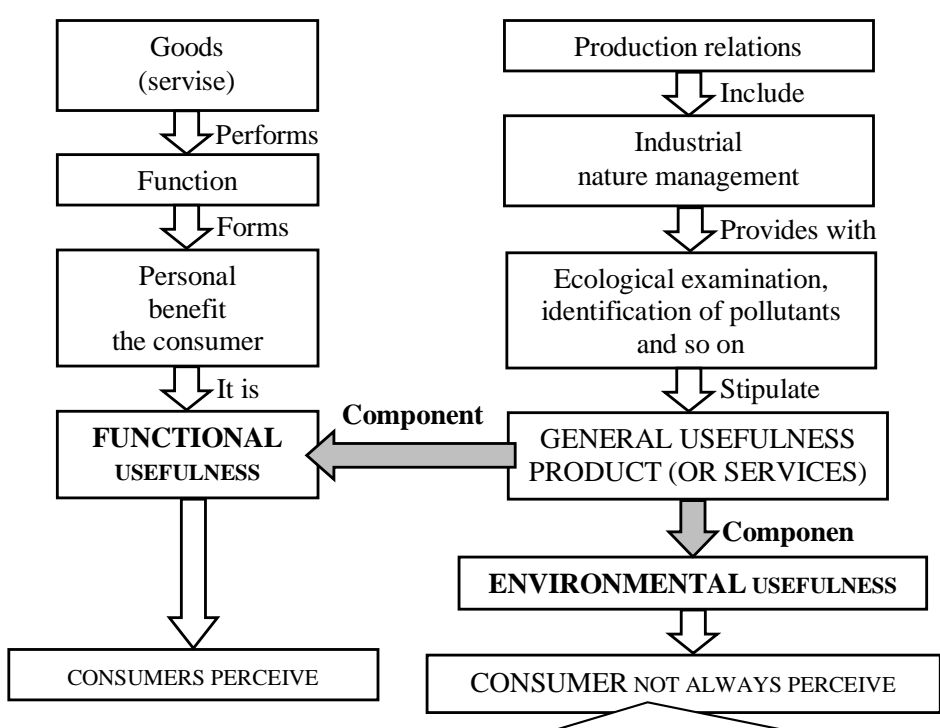

Which is due to insufficient level of environmental friendliness of enterprises (lack of appropriate material and technical base, waste management strategy), low ecological consciousness of consumers, insufficient level of financial well-being of people and other factors

Fig.1. Interconnection of functional and ecological usefulness of goods (or services) 


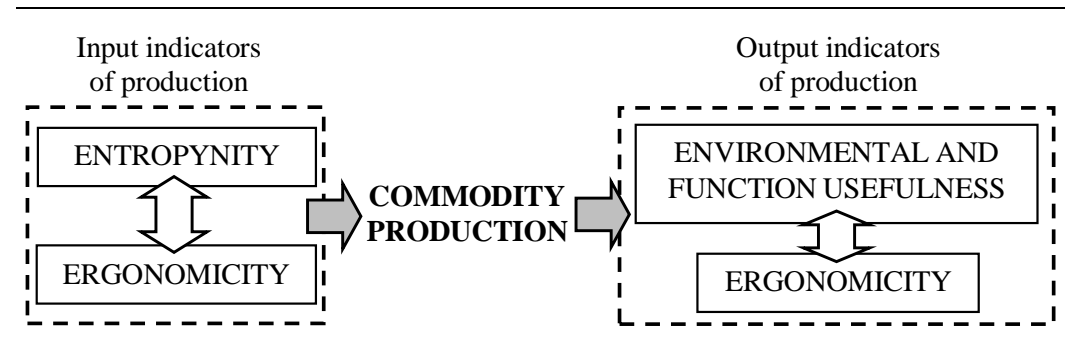

Fig. 2. The role of ergonomics at different stages of commodity production
In connection with this, the general usefulness of a product (service) (Pgu) is proposed to be divided into two components, which include both functional (Pf) and environmental (Pe):

$$
\mathrm{Pgu}=\mathrm{Pf}+\mathrm{Pe} \text {. }
$$

Environmental usefulness is the property of a product (service) to cause external envi-
itatively fixed; they relate to the ronmental effects (externalities) that are not qualitatively and quantitatively fixed; they relate to the
ability of the product at all stages of the life cycle to ensure and maintain the quality of the native environment and living conditions, without which can not support the normal physical and psychological state of man and the productivity of ecosystems.

If the ecological and functional usefulnesses determine the ergonomics with the help of the influence of production on the restoration of the resource-raw material potential of the environment "on the way out" from the production process, then "at the entrance” entropy establishes the potential of ergonomics, which directly depends on the currently available natural-material resources [10] (Fig. 2).

The basis for the development of ergonomics should be principles of the green economy, which operate within the limits of those entropy parameters that do not exceed the allowable norms of depletion of the resource and raw material base. As a result, they will not interfere with the process of ensuring the vital needs of future generations, thus creating an ergonomic social input "at the entrance". These principles create the basis for the development of environmental parameters that will meet the maximum permissible environmental pollution norms and will not endanger the further effective reproduction of ecosystems and, thus, ensure the ergonomics of social production "on the way out".

In summary, we can conclude that solving local environmental problems are the most promising area of modern ergonomics. Violation of the equilibrium in the environment as a result of active human activity significantly complicates its negative consequences of the problem that occurs in the workplace of a particular person. This should be taken into account when designing any activity for timely non-management, prevention or elimination of such factors. You can use existing experience, modern techniques and trained specialists in the field of ergonomics to comprehensively identify such factors, to thoroughly analyze them and to substantiate preventive or optimizing measures.

Conclusions. Thus, on the basis of the work done we can draw conclusions:

The necessity of analysis and research of ecological problems for increase of efficiency of ergonomic decisions is shown.

In order to reduce the rate of entropy growth in the anthropogenic sphere, it is necessary to identify, analyze and, if possible, eliminate the causes and consequences of violations of environmental equilibrium in the environment. For this purpose it is expedient to use new non-standard approaches, such as, for example, the complex application of ecological and ergonomic methods.

To represent the multifaceted spectrum of ergonomic relations, an obligatory step is the systemic combination of all the components that correlate with each other (including ecologic ones), into the overall structure of ergonomics, which will increase the safety of man and the environment.

\section{Література}

1. Мягченко О.П. Безпека життєдіяльності людини та суспільства. Київ: Центр учбової літератури, 2010. 384 c.

2. Definition and Domains of Ergonomics. URL: http://www.iea.cc/whats/ (Last accessed 12.06.2017)

3. Протасенко О.Ф., Івашура А.А. Екологічність робочого місця і простору. Открытые информационные и компьютерные технологии. 2016. Вип. 73. С. 118-126. 
4. Ульянова Е.А., Манжуров И.Л., Габова И.Я. Идентификация и оценка значимости экологических аспектов на промышленных предприятиях. Известия Самар. науч. Центра Рос. академии наук. 2011. T. 13. №1. С. 2089-2093.

5. Мигаль Г.В., Протасенко О.Ф. Проблемы экологического проектирования среды жизнедеятельности человека. Безпека людини у сучасних умовах: матеріали III Міжнар. наук.-метод. конф. Харьков, 2011. С. 150-152.

6. Abdul Raziq, Raheela Maulabakhsh. Impact of Working Environment on Job Satisfaction. Procedia Economics and Finance. 2015. 23. P. 717-725.

7. ,Пособие по наблюдению за условиями труда на рабочем месте в промышленности. Система Элмери / Лайтинен Х. и др. Охорона праці: науково-виробничий журнал. 2012. № 8. С. 42-53.

8. Workplace environment. media.rspp.ru. 2015. URL: media.rspp.ru/document/1/9/e/ 9ef017d1e4827978 ae7de076cb6388ef.pdf. (Last accessed 18.05.2017)

9. Мигаль Г.В., Протасенко О.Ф. Обеспечение функциональной и экологической устойчивости человека в СЧТС. Безпека людини у сучасних умовах: матеріали IV Міжнар. наук.-метод. конф. Харків. 2011. С. 126-128.

10. Погорелов С.Н., Горбунов Н.П. Современные тенденции в эргономике. Вісник Національного технічного університету «Харківський політехнічний інститут». Харків, 2016. №28. С. 120-125.

\section{References}

1. Myahchenko, O.P. (2010). The safety of human life and society. Kyiv: Tsentr uchbovoyi literatury.

2. Definition and Domains of Ergonomics. Retrieved from http://www.iea.cc/whats/.

3. Protasenko, O.F., \& Ivashura, A.A. (2016). Ecofriendlyness of a workplace and workspace. Open information and computer technologies. Vol. 73, 118-126.

4. Ulyanova, E.A., Manzhurov, I L., \& Gabova, I.Ya. (2011). Identification and evaluation of the importance of environmental aspects at industrial enterprises. Izvestiya Samar. nauch. Tsentra Ros. akademii nauk, Vol. 13, 2089-2093.

5. Migal, G.V., \& Protasenko, O.F. (2011). Problems of environmental designing of the environment of human life. Human security in modern conditions: materials III International. sci. method. conf. 150 -152.

6. Abdul Raziq, \& Raheela Maulabakhsh. (2015). Impact of Working Environment on Job Satisfaction. Procedia Economics and Finance 23, 717-725.

7. Laytinen, H., Rasa, P.L., \& Lankinen, T. et al. (2012). A manual on observing the conditions of work in the workplace in the industry. Elmer's system. Occupational Safety: Scientific and Production Magazine, 8, 42-53.

8. Workplace environment. (2015). media.rspp.ru Retrieved from: http://media.rspp.ru/document/ 1/9/e/9ef017d1e4827978ae7de076cb6388ef.pdf.

9. Migal, G.V., \& Protasenko, O.F. (2011). Ensuring functional and ecological stability of a person in the SSTS. Human security in modern conditions: Human security in modern conditions: materials IV International. sci. method. conf. pp. 126-128.

10. Pogorelov, S.M., \& Gorbunov, M.P. (2016). Current trends in ergonomics. Bulletin of National Technical University “Kharkiv Polytechnic Institute”. 28, 120-125. 